\title{
TOWARDS A VULNERABILITY-CENTRED PHENOMENOLOGICAL ETHICS: PERSONHOOD, HUMANITY AND BODILY PRECARIOUSNESS OF THE MEDIATIZED, EXILED SUBJECT
}

IRENE BREUER

\begin{abstract}
This paper examines the particular demands that vulnerability makes on ethics with respect to the exiled 'Other'. First, I briefly discuss the limit experience of exile in order to reflect on the notions of vulnerability and bodily precariousness as developed by J. Butler, M. A. Fineman, A. MacIntyre and M. Nussbaum. In the main part of the article, I emphasize E. Husserl's, E. Lévinas' and B. Waldenfels' ethical approaches. It is within this framework that I first inquire into the possibility of a vulnerability-centred ethics that would be both universal and particular. Second, I aim to develop an ontology of the moral subject that is based on the cultivation of values, virtues and emotions. This will lay methodological basis for a material axiology. Lastly, I want to account for the experience of encountering the Other, which proves to be of central importance in the context of the de-personalisation and de-humanisation of the human subject that itself results from the process of mediatization.
\end{abstract}

\section{Introduction}

It must be acknowledged, in view of the present global political and social situation, that our age is the age of the refugee, the displaced person and mass immigration. As Edward Said reminds us: "Exile [...] is the unhealable rift forced between a human being and a native place, between the self and its true home: its essential sadness can never be surmounted." ${ }^{1}$ But if true exile is a condition

1 Said Edward W., Reflections on Exile and other Essays, Cambridge, Harvard Univ. Press, 2001, p. 173. 
of terminal loss or a "damaged", mutilated life, as Theodor W. Adorno remarks, ${ }^{2}$ then we have to ask what is lost or mutilated here. It concerns, I want to suggest, a loss of attachment, not only to our roots, native place, community and collective identity, but also to a loss of language and with this, of the possibility of dialogue. But above all, it means the loss of the very possibility of acknowledging the personhood or even the humanity not just of the Other, but also of ourselves. This is an issue that deserves careful consideration especially in view of the policies that are presently decimating livelihoods. The modern media contribute to this process insofar as they bring about a de-personalisation of human life, reducing it to a mere representation and so cancelling out the possibility of any personal or emotional involvement with the experiential reality of the exiled persons. This media-induced dehumanisation is the main cause of the misunderstanding of exile and the seeking of refuge. Moreover, this mediatization does not describe its products in a neutral fashion, but it reduces them to a mere code. The subject is consequently "mediatized" ', to put it in Jean Baudrillard terms. And as Judith Butler concludes, in order "to convey the human, then, representation must not only fail, but it must show its failure" 4 .

It is in relation to this phenomenon of the failure of representation that Emmanuel Lévinas emphasizes that the vulnerable subject is the one whose being is broken: "Determination [of essence] is formed, and is already undone, by the clash [of beings]." ${ }^{5}$ Hence, a comprehension of the precariousness of the Other is the basis for any vulnerability-centred ethics, an ethics that should be both universal and tied to a formal axiology as well as particular, that is, able to account for the particular subject and its individual life. Edmund Husserl's personalistic ethics complies with both requirements: The subject is simultaneously a subject of acts of reason, who is responsible for its ethical convictions and for his acts, and a moral, embodied person, who embraces the search for positive values and is guided not only by reason but by love. But even though Husserl's ethics involves both universal and particular demands, it neither provides a developed material axiology that would determine essential value-properties necessary to account for the bodily

2 Cf. Adorno Theodor W., Minima Moralia. Reflections from Damaged Life: Reflections on a Damaged Life, E. F. N. Jephcott (transl.), New York, Verso, 2005.

3 Baudrillard Jean, Simulacra and Simulations, Sh. F. Glaser (transl.), Ann Arbor, MI: University of Michigan Press, 1995, p. 175.

4 Butler Judith, Precarious Life. The Powers of Mourning and Violence, New York, Verso 2004, pp. 142-144.

5 Lévinas Emmanuel, Otherwise than Being or Beyond Essence, Lingis A. (transl.), The Hague, M. Nijhoff, 1981, p. 4. 
needs of a vulnerable subject nor does it properly account for the vulnerability at play in the encounter with the other.

These are the issues at stake at Lévinas' and Martha Nussbaum's respective approaches: While on the one hand, Nussbaum develops a theory of basic social and economic goods such as "health, education, a decent level of welfare, shelter and housing" 6 as the complement of moral obligations, on the other hand, Lévinas indicates the role of the 'face'. The face is the testimony of a suffering that grounds an ethics that is prior to any ontology - a dimension that Husserl understands as pre-egoical, as one in which the subject is intertwined with others - and from which the absolute responsibility for the Other originates.

Actually, only the face-to-face encounter permits the recognition of the vulnerability of the Others - and of our own vulnerability. It is with respect of this latter phenomenon that Bernard Waldenfels undertakes a revision of Levinas' one-sided emphasis on responsibility and develops a responsive ethics which, grounded on reciprocal trust and confidence, demands a responsive politics that provides an answer to the needs of refugees.

Against the background of the preceding considerations, my intention in this article is twofold. First, I want to give an account of the present condition of the exiled and refugees with respect to their vulnerability and precariousness, an existential condition that is made still worse by the dehumanisation that arises from their representation in the media. Such a critical perspective requires that present discourses on vulnerability be framed within an analysis of the ontological determinations of what type of 'reality' our sensible body is, with a view to uncovering the source of our bodily vulnerability. I do this by drawing on Husserl's phenomenology of the body, which sketches the correlation between the modes of being of the body and the conditional qualities affecting it. But an adequate response to such a state of bodily neediness demands the development of a vulnerability-centred phenomenological ethics, which should not only specify spiritual values as Husserl's, Lévinas' and Waldenfels' ethics do, but existential values that can properly account for our bodily and social requirements. Hence, my second aim in this paper is to provide the basis for a material axiology that determines the social and economic goods necessary to lead a dignified human life.

6 Nussbaum Martha C., Political Emotions, Why Love Matters for Justice, Cambridge, Harvard Univ. Press, 2013, p. 123. 


\section{Embodied Vulnerability and the Exiled Subject}

The semantic field of exile has been greatly expanded. Exile in its original sense meant banishment, separation as punishment, ostracism by the community or the collective; a forced severance of organic ties to a place called home, without which life lost its meaning. For William Gass, Socrates - choosing death over exile - provides the paradigmatic example of this: "above all, exile is amputation, a mutilation of the self, because the society Socrates lives in is an essential part of his nature, a nature he cannot now divide." Johannes Evelein agrees, stressing that exile "is a rupture with oneself, a terrible loss synonymous with, possibly even worse than, death". "The exile's plight prevents growth, transformation or redemption. This goes hand in hand with the view that what "makes exile the pernicious thing it is, is not really the state of being away, as much as the impossibility of ever not being away - not just being absent, but never being able to redeem this absence" , as André Aciman rightly points out. Hence, it is the permanence of an unredeemable absence that properly defines exile. Exile is the existential limit experience of estrangement par excellence. ${ }^{10}$ Migrants and exiled people remind us of our bodily vulnerability and precariousness before the blows of fate.

It is important to acknowledge in this context that not only exiled subjects, but also "[h] uman life is conditioned by vulnerability"11, as Catriona Mackenzie, Wendy Roberts and Susan Dodds, the editors of a pioneering volume on vulnerability and ethics claim. In this connection, Judith Butler's and Martha A. Fineman's reflections on the ethics of corporeal vulnerability posit vulnerability as the ontological condition of our embodiment. But, as Butler stresses, vulnerability is also relational, insofar as it is related to "other humans, living processes and inorganic conditions and vehicles for living, such as infrastructure, understood as environment, social relations and networks of support."12 She claims "vulnerability

7 Gass William H., "Exile”, in Gass, W., Finding a Form, New York, Knopf, 1996, p. 218.

8 Evelein Johannes F., Editor's Foreword to Evelein Johannes (ed.), Exiles Travelling. Exploring Displacement, Crossing boundaries in German exile arts and writings 1933-1945, Amsterdam, Rodopi, 2009, p. 13

9 Aciman André, Foreword to Aciman André (ed.), "Permanent Transients", in Letters of Transit. Reflections on Exile, Identity, Language and Loss, New York, The New York Press, 1999, p. 10.

10 Cf. Breuer Irene, "Die Schranken der Fremdheit. Mario Benedetti und die Exilerfahrung aus phänomenologischer Sicht", in Mönig Julia; Orlikowski, Anna (Hrsg.), Exil interdisziplinär. Exilformen, Beweggründe und politisch-kulturelle Aspekte von Verbannung und Auswanderung, Würzburg, Königshausen \& Neumann 2015, pp. 131-137.

11 Mackenzie Catriona; Rogers, Wendy; Susan Dodds (eds.), Vulnerability. New Essays in Ethics and Feminist Philosophy, New York, Oxford Univ. Press, 2014, p. 1.

12 Butler J., "Bodily vulnerability, coalitions, and street politics", in Butler J., author; Sabadell-Nieto Joana, editor; Segarra Marta, editor, Differences in common: gender, vulnerability and community. 
implicates us in what is beyond us yet part of us"13, it constitutes an essential element of our embodiment. Fineman, who takes up Butler's notion of corporeal vulnerability, puts this idea in the context of a critique of liberal legal and political theory, in order to argue for a "responsive state" 14 , a state that provides the means and mechanisms whereby the vulnerable subject may become resilient to the social and material implications of vulnerability. Because it is a universal condition, Fineman argues that "vulnerability must be at the heart of our idea of social and state responsibility". 15

Human vulnerability arises, as both Butler and Fineman ${ }^{16}$ claim, from our ontological condition as embodied beings. There is therefore neither a position of "invulnerability" nor a self-sufficient, autonomous subject. Dependency and vulnerability are therefore not "deviant, but natural and inevitable." ${ }^{17}$ As Butler puts it, "the body is constitutively social and interdependent" and it is the embodied vulnerability before others and fate that makes human life precarious. ${ }^{18}$ Hence, vulnerability, precariousness and dependence are intertwined. On Butler's and Fineman's views, then, vulnerability is both an ontological feature of our embodiment, insofar as we are both exposed to suffering and contingencies, and relational, insofar as we are vulnerable to varying degrees to power relations and to harm with respect to the dependencies and needs of our particular situation and our capacity to act and respond to this.

\section{The 'Reality' of the Sensible Body - Husserl}

It is my view that Butler's and Fineman's innovative insights must be framed within an analysis of the ontological determinations of what type of 'reality' our sensible body is, in order to uncover the source of our bodily vulnerability. Edmund Husserl's phenomenological ontology investigates the modes of being of the body in light of its dependence on the conditional qualities affecting it from the

Amsterdam, Rodopi, 2014, pp. 97-119, here p. 103 and 105.

13 Ibid., p. 114.

14 Fineman Martha Albertson, "The Vulnerable Subject and the Responsive State", in Emory Law Journal, vol. LX, 2, Atlanta, 2010, pp. 251-275, here p. 251.

15 Fineman M. A., "Equality, Autonomy, and the Vulnerable Subject in Law and Politics", in Fineman M. A., Grear Anna (eds.), Vulnerability, Reflections on a New Ethical Foundation for Law and Politics, Ashgate, 2013, p. 19.

16 Fineman M. A., “The Vulnerable Subject and the Responsive State”, art. cit., p. 268.

17 Ibid., p. 17.

18 Cf. Butler J., Precarious Life, op. cit., cf. Introduction. 
outside world. He focuses on the functional correlation between states of bodily consciousness and the material circumstances to which the body is exposed. The intimate experience of such occurrences reveals the bodily capacity to feel or, in Husserl's term, an Empfindsamkeit or a "sensitiveness of the Body"19. This bodily sensitiveness is related to external solicitations and accordingly, our physical body and our soul as a unity exhibit a "dependence 'on circumstances'." ${ }^{20}$ Husserl distinguishes between different types of circumstances, referring to the "psychophysical (or, better, 'physio-psychic') side", which comes from its own bodily component, the "idiopsychic side", that is, conditionalities arising from previous experiences and finally "the intersubjective relations of dependence of psychic reality" that are due to the social environment. ${ }^{21}$ Husserl's distinction between the three kinds of conditional properties of bodily consciousness aims to show how the body is vulnerable and exposed to both worldly conditions and the Empfindsamkeit of the flesh. In Husserl's words: The "states of sensations (Empfindungszustände)" depend on "the concomitant system of real circumstances under which it senses (empfindet)." 22 Even though body and consciousness have different ontological natures, Husserl discusses the hypothesis of a "psychophysical parallelism and interaction" 23 . This hypothesis postulates a reciprocity between the two realms. But Husserl ultimately rejects this parallelism using two different kinds of arguments. The first are of an ontological and methodological nature. They contrast the "essential laws of consciousness" 24 , which are absolutely true, to natural laws, which are subject to "contingent changes" 25 . The second ones consider the "temporal determination of a conscious lived experience" 26 . The structure of internal time consciousness and the marginal consciousness of the temporal horizons of a given sensation can hardly be located at an "objective temporal point of the cerebral stimulation" 27 . Husserl concludes that even though "one can radically refute parallelism $[. .$.$] nothing at all is decided in favour of interaction (Wechselwirkung)"28$

19 Husserl Edmund, Ideas Pertaining to a Pure Phenomenology and to a Phenomenological Philosophy, Second Book. Studies in the Phenomenology of Constitution, Ideas II, Rojcewicz Richard, Schuwer, André (transl.), Dordrecht, Kluwer, 1989, \$ 40, p. 162. 
between consciousness and the brain. What Husserl clearly dismisses is "a univocal determination of spirit through merely natural dependency" ${ }^{29}$. This is "unthinkable" 30 for him. Husserl therefore does not deny that we are determined or even naturally influenced by our surrounding world, but he maintains that our Ego and its conscious life, because it is "absolute, irrelative" 31 , is ontologically and methodologically independent of nature.

Although no strict parallelism can be sustained, Husserl affirms that insofar as an Ego constitutes the surrounding world, "it allows itself to be determined by its 'over and against" and hence it acquires an "originary individuation" 32 . This means that, although the Ego and the world are different in nature, we owe our individuation at least in part to the influence of our surrounding world. Moreover, our bodies in their materiality obviously depend on the resources provided by nature for their subsistence. But bodies are also reciprocally or mutually implicated in another, double sense: The constitution of my own body is inseparable not only from my experience of the foreign body but from the modifications the latter introduces in my own flesh. ${ }^{33}$ There is therefore a reciprocity not only between body (Leibkörper) and surrounding world as material realities, but between two lived bodies (Leiber) as psychophysical ones: The latter reciprocity thus forms the ultimate ground not only of a bodily, but of a social intersubjectivity, thus laying the basis for a community. In conclusion, it is our natural bodily sensitivity and neediness that makes us vulnerable to material circumstances. This correlation, together with other considerations that I will introduce in the following, could provide the ontological ground for the development of a material axiology.

\section{Towards an Ethics of Vulnerability}

\subsection{The Moral Significance of Vulnerability - A. Maclntyre and M. Nussbaum}

The concept of the vulnerable, embodied subject opens up a new theoretical perspective for ethics. To begin with, if we follow Alisdair MacIntyre and Martha C. Nussbaum, an ethics that has emphasized the virtues of autonomy has led to

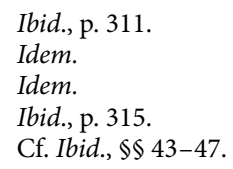


the failure of moral philosophy hitherto to account for embodiment. ${ }^{34}$ On the one hand, as MacIntyre explains, this failure is due to the "belief that our rationality as thinking beings is somehow independent of our animality." 35 On the other hand, as Nussbaum emphasizes, this oblivion of vulnerability can be traced back to the Stoics, who identified personhood with reason, an identification that also characterizes Kant's deontological moral theor ${ }^{36}$. In this connection, Fineman, in agreement with MacIntyre, argues that "[a]utonomy is defined in terms of expectations of self-sufficiency and independence for the individual." 37 This understanding of individual autonomy is difficult to reconcile "with concepts such as dependency or vulnerability." 38 This overemphasis on rational agency and on individual autonomy, an over-emphasis that has given rise to the "virtues of independent rational agency" 39 within a deontological ethics, needs to be counterbalanced by a virtue ethics that accounts for what MacIntyre calls "the virtues of acknowledged dependence" 40 . Both types of virtues are connected insofar as "a failure to understand this is apt to obscure some features of rational agency" 41 . What the virtues of acknowledged dependence require from us are types of actions that are at one and the same time "just, generous, beneficent and done from pity" 42 . These virtues arise from the education focused on dispositions to act in the ways described and to "sustain relationships of uncalculated giving and graceful receiving" ${ }^{3}$. Hospitality is just one example of a duty that involves a disposition, since it has to be willing and it extends beyond the realm of one's own community. ${ }^{44}$ However, MacIntyre stresses that hospitality must be accompanied by another moral virtue towards others, misericordia, as a form of charity in Aquinas' terms. By "misericordia" 45 we give what the Other needs, which thus gives rise to neighborship and ultimately to community. Such dispositions are required in practicing the "virtue of just generosity" 46 . This virtue is characterized by three main traits: By giving rise

34 Cf. MacIntyre Alasdair, Dependent Rational Animals. Why Human Beings Need the Virtues, Illinois, Open Court, 1999, p. 4 and 8; Nussbaum M. C., Frontiers of Justice, Cambridge, Harvard Univ. Press, 2006, pp. 130-132.

35 MacIntyre A., Dependent Rational Animals, op. cit., p. 5.

36 Nussbaum M. C., Frontiers of Justice, op. cit., p. 130.

37 Fineman M. A., “The vulnerable subject and the responsive state”, art. cit., p. 259.

38 Ibid.

39 MacIntyre A., Dependent Rational Animals, op. cit., p. 8.

40 Ibid., p. 9.

41 Ibid., p. 8.

42 Ibid., p. 121.

43 Idem.

44 Ibid., p. 123.

45 Ibid., p. 121.

46 Ibid., p. 122. 
to communal relationships that are affectively grounded, it extends beyond one's own community to embrace strangers or foreigners in relationships of hospitality and attends to their needs through the exercise of misericordia. ${ }^{47}$ This virtue of generosity, i.e. the "virtues of giving" 48 , requires that the giver is not calculating, i.e. cherishing an expectation that the giving and receiving will be proportional, while the counterpart, the "virtue of receiving" 49 entails gratitude towards the giver and "forbearance towards the inadequate giver." ${ }^{50}$ Hence, whereas Fineman opposes autonomy and vulnerability, MacIntyre rethinks the concept of autonomy and recognises human vulnerability through the virtues of acknowledged dependence.

Nussbaum also recognizes the normative significance of human vulnerability and develops a teleological ethics based on the cultivation of emotions, an ethics that regards feelings and emotions as forces inducing moral practices and as taking place in a particular social context. She stresses that "nobody is ever self-sufficient" 51 and emphasizes "the importance of care in times of dependency." 52 But she thinks that citizens in a just society need more than just care: They need "liberty and opportunity" 53 and the chance to form "other political relationships that are chosen and not merely given." ${ }^{4}$ Hence, her own Aristotelian/Marxian approach to dignity is based on the material and social prerequisites for living a dignified human life. Nussbaum therefore concludes that "need and capacity, rationality and animality, are thoroughly interwoven, and that the dignity of the human being is the dignity of a needy enmattered being" ${ }^{55}$ whose rational capacities, in contrast to its relatively stable needs, evolve in time. Furthermore, social cooperation is not at odds with a revised conception of liberalism insofar as it is understood as "complex and multiple, including love, respect for humanity, and the passion for justice, as well as the search for advantage." ${ }^{56}$ Conceiving this political means implies recognizing that human beings are "vulnerable temporal creatures, both capable and needy" 57 , as well as vulnerable to events they do not control. This state of neediness

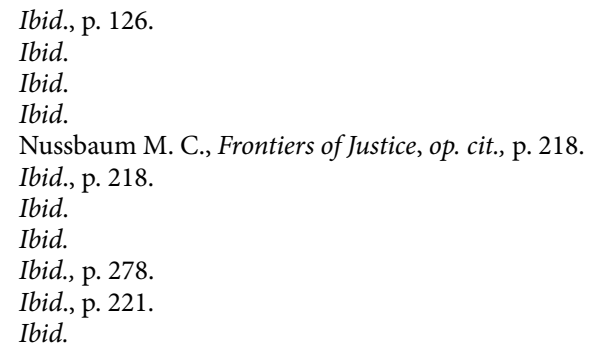


and this lack of self-sufficiency are brought to the fore by emotions. ${ }^{58}$ Nussbaum has a normative view of emotions: she assumes that they should give rise to "mutual respect and reciprocity" 59 , that they can allow the consideration of people "as ends rather than as means, and as agents rather than simply as passive recipients of benefits" 60 and finally, that they can include "concern for the needs of others" 61 .

This concern for the needs or pain of another involves an acknowledgment of a "similar vulnerability" 62 , which latter is based on a sense of "commonness" 63 which grounds a community. As Aristotle's conception of eudaimonia shows, in order to feel compassion for the other, a person must take the wellbeing of another to be a part of their own wellbeing; they must make themselves "vulnerable in the person of another." 64 Accordingly, it must be acknowledged that human life, as Aristotle notes in his Nicomachean Ethics ${ }^{65}$, is never fully autarchic. For Nussbaum, however, the aforementioned eudaimonistic judgment that is based on empathy, from which the moral obligation arises, needs to be complemented by a theory of the "basic human goods" 66 that are required to meet our needs for nutrition, shelter, bodily integrity, attachment, education, health and social life, to name just a few. Fineman and Butler both claim that it is the state's duty to provide basic resources that promote resilience with the aim of fostering autonomy, i.e. promote people's capacity for agency. Nussbaum holds a similar point of view but stresses the duty of the society as a whole to guarantee all citizens the "set of capabilities or opportunities for functioning" 67 required by human dignity. Nussbaum sees "life", "bodily health" and "integrity", "senses, imagination and thought", which is achieved mainly through education, "emotions", i.e. the ability to have attachment to things and other people; "practical reason", i.e. the ability to conceive of the good and to critically reflect; "affiliation", i.e. the ability to interact socially with reciprocal respect ; "play" and finally, "control over one's environment", i.e. the ability to participate in politics and to hold property as amongst these capabilities and opportunities. ${ }^{68}$ Nussbaum's capabilities theory not only has the merit of

58 Nussbaum M. C., Upheavals of Thought. The Intelligence of Emotions, Cambridge, Cambridge Univ. Press, 2001, p. 12.

59 Idem.

60 Idem.

61 Idem.

$62 \quad$ Ibid., p. 318.

$63 \quad$ Ibid., p. 317.

64 Ibid., p. 318.

65 Cf. Aristoteles, Nikomachean Ethics, abbrev. Eth. Nic. X, 1178a23-b7.

66 Nussbaum M. C., Upheavals of Thought, op. cit., p. 376.

67 Ibid., p. 416.

68 Ibid., pp. 417-418. 
considering the needs of a subject taken as a person in the fullest sense of the term, but it also establishes a threshold of basic entitlements that aims to promote a person's capacity for autonomy. These entitlements can be read, I want to suggest, as economic, social and personal values that provide the basis for a material axiology that accounts for the correlation between our body and its material environment.

\subsection{The Ontology of the Moral Subject - Husserl}

Such an understanding of ethics would necessarily have to explain why we are obliged to protect vulnerable people. A moral obligation may arise out from empathy, as Aristotle shows, or from an ethical demand as Husserl's ethics maintains. ${ }^{69}$ What Husserl's ethics offers for an ethics of care like that outlined above is precisely the axiological grounding required by a vulnerability-centred ethics, that is, an ethics that while universal, also has to account for the particularities of the individual lives at issue. Husserl's early ethics is characterised precisely by the discovery of a sphere of fundamental a priori valid laws for ethics. In this early ethics the laws of formal axiology and formal practices are parallel to the formal logic or the science of formal laws of theoretical reason. ${ }^{70}$ These a priori rules have an ideal character and govern our thinking, evaluating and willing. ${ }^{71}$ The first example of such a formal law of the will is the categorical imperative that Husserl takes from Brentano. It says: "Do the best that is attainable! [Tue das Beste unter dem Erreichbaren!]"72 This imperative is a noetic expression. "Objectively, the expression would be: the best attainable within the entire practical sphere is not merely the best comparatively speaking, but rather the sole practical good." 73 Although there is an objective a priori formal norm, the personal situation is always individuated within the stream of experience. ${ }^{74}$ Husserl's axiology, as opposed to Kant's, is a "logic of the heart [Gemüt]"75. It is based on how the heart relates to what appears

69 Cf. Breuer I., "The Ego as Moral Person. Husserl's Concept of Personhood in the Context of his Later Ethics", in Miscellanea Anthropologica et Sociologica 2019, 20(1), Plotka Witold (ed.), "Phenomenology, Practice and Action: Perspectives on East-Central Europe”, pp. 15-35. Cf.: https://czasopisma .bg.ug.edu.pl/index.php/maes/article/view/3152/2576.

70 Husserl E., Hua XXVIII, Vorlesungen über Ethik und Wertlehre (1908-1914), Nenon Thomas, Sepp Hans Rainer (eds.), Dordrecht, Kluwer, 1974, pp. 3-69.

71 Ibid., pp. 74-101.

72 Ibid., p. 221.

73 Ibid., as quoted in Melle Ullrich, “The Development of Husserl's Ethics”, in Études Phénoménologiques 13-14, pp. 115-135, here p. 120.

74 Husserl E., Hua XXVIII, op. cit., p, 149.

75 Hart James, The Person and the Common Life: Studies in a Husserlian Social Ethics, Dordrecht, Kluwer, 1992, p. 299. 
as good and bad. ${ }^{76}$ The categorial imperative thus combines absolute ethical laws with a demand for an analysis of our affective motivations and the practical possibilities that are or might be attainable at the moment of choice. As such, it is a hypothetical principle. But pure axiological laws do not provide us with criteria for the determination of the value-properties needed to establish what is best. For this, we need a material axiology and praxis. ${ }^{77}$ Husserl did not systematically and in detail develop this material aspect of axiology and ethics either in his early or in his later ethics, as Ullrich Melle points out. ${ }^{78}$ Later on, however, Husserl questions the rational universalism and objectivism of his ethics, because pure axiological laws do not provide the material value-content necessary to justify ethical choices. ${ }^{79}$

I believe that the solution to this problem lies in the consideration of the subjective values of love that are the object of the subjective ethical will on the one hand and the acknowledgment of the Others' wills and values on the other. This new orientation of Husserl's ethics amounts to a questioning of his ethical rationalism as based on the categorical imperative. It also implies a change in the ontology of the person: the deepest being of the person is not to be found in reason but in love. "Personal values (personale Werte)" 80 of love, such as love for one's own child or for a friend, for personalities of a higher order such as one's own family or community or love of the neighbour "make up the largest part of the values of an absolute ought" 81 . This is very important for a social ethics, insofar as the ideal of rational humanity is to be found in the idea of a community of love, wherein the subjects reciprocally aid one another and take the needs of others as their own. This communalization of lives grounded on emphatic perception gives rise to solidarity.

But the Other is not accessible to me only through emphatic perception because we are interwoven with the other already at an originary level, i.e. in the sphere of passivity. I want to suggest that this is the sphere of the originary, undifferentiated 'we': an actual 'being-for-each-other' is presupposed by any constitution of personal relationship with the Other. This is because we are originally conjoined

\footnotetext{
Ibid.

Husserl E., Hua XXVIII, op. cit., p. 139.

78 Melle U., "From Reason to Love", in Drummond John, Embree Lester (eds.), Phenomenological Approaches to Moral Philosophy: A Handbook, Dordrecht, Kluwer, 2002, p. 236.

79 Husserl E., Hua XXVIII, op. cit., pp. 419-422.

80 Husserl E., Hua XLII, Grenzprobleme der Phänomenologie. Analysen des Unbewusstseins und der Instinkte. Metaphysik. Späte Ethik. Texte aus dem Nachlass (1908-937), Sowa Rochus, Vongehr Thomas (eds.), Dordrecht, Springer, 2014, p. 337. Idem.
}

81 
in a community of drives in the manner of an "intentional intermingling". ${ }^{82}$ Husserl understands this sphere as "radically pre-egoical (radikal Vor-Ichlich)"83: the sphere of "passivity devoid of Ego [ichlosen ("Passivität")]".84 This pre-ontological level is the realm where, in Lévinas' terms, my radical responsibility for the other originates. We gain access to this sphere through the transcendental reduction, which shows the intertwining of responsibilities and duties. ${ }^{85}$

Despite being a life out of "absolute responsibility" 86 , it must be freely chosen, i.e. it must be loved and willed. In contrast to Lévinas' conception, which will be discussed later, for Husserl the subject must recognize the necessity of self-responsible agency. Insofar as each one of us is co-responsible for the other's decisions and agency, a life of "universal and absolute self-responsibility (universaler und absoluter Selbstverantwortung)" arises. ${ }^{87}$ This means that from the outset one's life is connected to the lives of Others, such that our sense of agency is always intersubjective: we are absolutely responsible for each other. In later reflections that date from round about 1924, Husserl recognizes that it is the heart that sets values and it is cognition that takes responsibility for the truthfulness of these values. ${ }^{88}$

Hence, the absolute ought is no longer the absolute ground of ethics, but it is itself founded on ethical love and care. ${ }^{89}$ Even universal and absolute science is based on this radical responsibility for Others ${ }^{90}$ which latter arises from the sphere of universal ethical love for the Other in which I am originary interwoven. This ethical love is synonymous with an absolute overriding duty, which in its concretization is dependent upon the respective situation of action and the domain of practice.

Insofar as this absolute ought is grasped in its essential universality and in its situational relativity, it is conceived as an absolute law that is expressed in sentences with normative predicates. The taking of a position where a person orders his or her life as a whole under the guidance of this true self, i.e. the primary ethical task, is called "the ethical truth of the person (ethische[] Wahrheit der Person)"

82 Husserl E., Hua XV, Zur Phänomenologie der Intersubjektivität. Texte aus dem Nachlass. Dritter Teil: 1929-1935, Kern Iso (ed.), The Hague, M. Nijhoff, 1973, p. 366.

83 Ibid., p. 598.

84 Ibid., p. 595.

85 Husserl E., Hua VIII, Erste Philosophie (1923/24). Zweiter Teil. Theorie der Phänomenologischen Reduktion, Boehm Rudolph (ed.), The Hague, M. Nijhoff, 1959, p. 195.

86 Ibid., p. 199.

87 Ibid., p. 198.

88 Ibid., p. 194.

89 Ibid., p. 180.

90 Ibid., pp. 193-202.

$91 \quad$ Ibid., p. 297. 
that has both a formal-logical as well as a pre-logical, "situational" character.92 The absolute ought, as that which is required for each individual's self-realization and true self-preservation, is an instance of the general features of the categorical imperative that determines the best on the basis of a correctly motivated will. ${ }^{93}$ Hence, the absoluteness and universality of the ideal "ought to be" of a person or a community is tied, for the individuals, to the relativity of their respective situations, experiences and ultimately, to the subjective values of love.

The ontology of the ethical subject thus combines universal and particular demands which have their origin in the universal ethical love that is the ultimate meaning of the absolute ought. In Husserl's words, "it belongs to the 'essence' of each personal individuality to have a realm of personal decisions, personal love, personal ought $[. .$.$] , types, classes of personal values and corresponding general$ and a priori norms." ${ }^{\prime 4}$ But it is clear that an individual ethics opens out on to a social, communitarian ethics. True love of self is inseparable from true love of the neighbour. ${ }^{95}$ The spiritual life of both, the individual person or a social personality of a higher order, i.e. a community, is a personal life only to the extent that a person can build up an ethical will in response to its capacity to conceive of the wholeness and unity of his life.

In conclusion, For Husserl being a person means being a moral person only to the extent that it is embedded in a community: being a moral person is being a social being who engages in the love-driven pursuit of rationality and self-determination. This ethical striving towards self-determination and self-justification which permeates our life as a whole can be understood as the foundation of Husserl's phenomenology, which is determined by "a philosophical ethos" 96 . As Henning Peucker remarks, this is the ethical striving for a true life wherein all acts can be ideally justified and accounted for ${ }^{97}$ and it is ultimately driven by love.

92 Idem.

93 Husserl E., Hua XXXV, Einleitung in die Philosophie. Vorlesungen 1922/23, Goossens Berndt (ed.), Dordrecht, Kluwer, 2002, p. 45. Cf. Hart J., The Person and the Common Life, op. cit., p. 318.

94 Husserl E., Hua XLII, op. cit., p. 344.

95 Cf. Husserl E., Hua XXXVII, Einleitung in die Ethik. Vorlesungen Sommersemester 1920/1924, Peucker Henning (ed.), Dordrecht/Boston/London, Kluwer, 2004, pp. 10-12; Husserl, E., Hua XIV, Zur Phänomenologie der Intersubjektivität. Texte aus dem Nachlass. Zweiter Teil: 1921-1928, Kern Iso (ed.), The Hague, M. Nijhoff. 1973, pp. 165-184; pp. 192-204.

96 Peucker Henning, "Die ethischen Grundlagen von Husserls Philosophie”, in Journal Phänomenologie 36, 2011, p. 10.

97 Idem. 


\subsection{The Face - Lévinas; Responsive Ethics - Waldenfels}

Husserl's ethics provides us with an answer to the problem of how an ethical demand guided by love and faith, which takes place within a community whose subjects care for each other lovingly, brings forth self-responsibility and agency. However, although Husserl's ethics involves both universal and particular demands, it does not properly account for the ethical implications at play in and before the face-to-face encounter with the other. This is precisely what is at stake in Lévinas' account of the role the 'face' plays in the understanding the vulnerability of the Other: the face is the testimony of a suffering and a vulnerability. As such it embodies a call for peace that cannot be ignored. While in Totality and Infinity the possibility of ethics is located in the concrete encounter with the transcendent Other, in Otherwise than Being the responsibility inherent in subjectivity is pre-ontological, i.e. prior to any real encounter with the Other. Hence, the responsibility is "justified by no prior commitment" 98 , it is, in a word, absolute. The self is already "substituted" for the Other here, beneath self-consciousness and prior to any choice. "Substitution" 99 is the term Lévinas uses to characterize the immanence of the Other in the very subjectivity of a subject. It implies that the self is radically and absolutely responsible for the Other prior to any ontological constitution of the self and to any particular ethics based on moral imperatives. It is, as we have seen, a realm that Husserl defines as a pre-egoical or as an intersubjective "intermingling".

Lévinas' ethics begins with sacrifice and giving, rather than with limiting the answer to the Other's explicit call. It shows a sensitivity towards the problem of exposition that crystallises in the claim that the Other is radically transcendent, whose transcendence is irreducible to ontology. This approach might seem at first to be incompatible to Husserl, for whom the responsibility towards the Other forms the ground of a social ontology. For Lévinas, the relation of one to the Other is marked by a non-spatial proximity, that of an obsession. Being obsessed by the other, the subject becomes a hostage. ${ }^{100}$ As Lévinas puts it, "[r] esponsibility in obsession is a responsibility of the ego for what the ego has not wished, that is, for the others"101. To be infinitely responsible means to carry the burden of even the Other's own responsibility for me.

\footnotetext{
${ }^{98}$ Lévinas E., Otherwise than being or beyond essence, op. cit., p. 102.

99 Ibid., p. 13, pp. 113-118.

100 Ibid., p. 112.

101 Ibid., p. 114.
} 
Lévinas approaches this absolute and radical responsibility for the Other that defines the very possibility of ethics ${ }^{102}$ and its related problems of exposition and representation in his conception of the "face", a conception that combines both the acknowledgment of the precariousness of life and the prohibition of violence, ${ }^{103}$ as Butler points out. For Lévinas, "the approach to the face is the most basic mode of responsibility [...]. The face is not in front of me (en face de moi), but above me." 104 The face is the very structure that suspends phenomenology, it is not "seen" nor can it "become a content, which your thought would embrace"105. As such, the face cannot be object of the thematizing gaze. ${ }^{106}$ On the contrary, it is "signification and signification without context"107, i.e. the face is signification by itself: "you are you." 108 The face "leads you beyond" 109 and because it is "uncontainable" 110 , it cannot be a phenomenon and is thus also beyond representation. The ethical relation of love for the other does not arise out of an affective demand that guides the exercise of rationality, it is not a means of achieving self-responsibility and agency. It is previous, prior even to the foundation of the self as distinct from the Other. ${ }^{11}$

That which constitutes the Other is not the conjunction of spatial localization and bodily kinaesthetic sensations in Husserl's terms, but the intentionality of an emotion that reaches out for something or someone outside the self, even before I can assume its or their existence. The ontological terms "I" and the "Other" thus stem from the ethical emotion of love. If love is supra-ontological, then it is the task of responsibility to ground ethics. Being infinitely responsible arises from out of love, it implies that the ontological right to existence of the Other is previous to mine. ${ }^{112}$ This right to existence invoked by the imperative to preserve the life of the Other and contained in the dictate "you shall not kill" implies that the Other's rights precede my own right to self-preservation. It is the imperative call of the

102 Cf. Bernasconi Robert, Keltner, Stacy, "Emmanuel Lévinas", in Phenomenological Approaches to Moral Philosophy, op. cit., pp. 249-268, here p. 26

103 Butler J., Precarious Life, op. cit., p. xvii.

${ }^{104}$ Lévinas E., Kearney, Richard, "Dialogue with Emmanuel Lévinas", in Face to face with Lévinas, Cohen Richard (ed.), State Univ. of N.Y. Press, 1986, pp. 13-34, here p. 23.

105 Lévinas E., Ethics and Infinity. Conversations with Philippe Nemo, Cohen R. (transl.), Pittsburgh, Duquesne Univ. Press, 1985, p. 86.

106 Lévinas E.: Totality and Infinity. An Essay on Exteriority, Lingins A. (transl.), The Hague, M. Nijhoff, 1979, p. 86: "The Other eludes thematization. [...] The Other measures me with a gaze incomparable to the gaze by which I discover him."

107 Lévinas E., Ethics and Infinity, op. cit., p. 86.

108 Ibid.

109 Ibid., p. 87.

110 Ibid.

111 Cf. Lévinas E., "Dialogue with Emmanuel Lévinas”, op. cit., p. 25.

112 Idem. 
Other's face, a call that shows its "precariousness and defenselessness"113, that gives rise to an infinite responsibility. A face is "signification", i.e. it conveys meaning prior to being grasped by any representation, which means "the ethical becomes the only means of signification". ${ }^{114}$

Lévinas offers a conception of ethics that rests upon the precariousness of the Other's life, evidenced in the face of the Other. However, Lévinas does not provide us with the resources to thematize an approach to the Other in terms of mutual recognition and reciprocity. His approach is based in an absolute responsibility within the self that does not call for a response. However, it is precisely this sphere of absoluteness that challenges any established ethical conception because it questions the very foundation of such a conception. This leads Robert Bernasconi and Stacy Keltner to stress that an "[e]thics as an ethics of suspicion is an infinite task." 115 In this regard, Bernard Waldenfels' "responsive ethics" has the merit of changing this one-sided emphasis on responsibility that was constitutive of Lévinas' ethics. Waldenfels' ethics answers the question of how a demand that originates from the Other can be transformed into a relationship based on the reciprocity of trust.

Waldenfels claims the reason for Lévinas' apparent neglect of this phenomenon is as follows: the unconditioned demand cannot arise from benevolence insofar as this would imply expectation and comparison. In the best case, the others would concern me as my friends do, which would mean that an "alienness that exceeds any common order would be suppressed." 116 Trust must not originate from our expectations but from the confidence we "give" and inspire if we are to maintain and respect the core of the otherness of the Other and to ensure their "accessibility in genuine inaccessibility, in the mode of incomprehensibility" 117 in Husserl's terms. This would guarantee that the alien is experienced as "heterogeneous"118 in our encounter with them and avoid making trust into an "enlarged form of self-confidence"119. Waldenfels argues to the extent that this unconditioned trust

113 Lévinas E., "Peace and Proximity", in Peperzak, Adrian, Critchley Simon, Bernasconi Robert (eds.), Emmanuel Lévinas. Basic Philosophical Writings, Bloomington, Indiana Univ., Press, 1996, p. 167.

${ }^{114}$ Ibid., p. 261.

115 Bernasconi R., Keltner, S., “Emmanuel Lévinas”, op. cit., p. 266.

116 Waldenfels B., "Responsive Ethics", in Zahavi Dan (ed.), The Oxford Handbook of Contemporary Phenomenology, New York, Oxford Univ. Press, 2012, p. 423-441, here p. 434.

117 Husserl E., Hua XV, op. cit., p. 631.

118 Cf. Steinbock, Anthony J., Home and Beyond. Generative Phenomenology after Husserl, Illinois, Northwestern Univ. Press, 1995, p. 244.

119 Waldenfels B., "Responsive Ethics", art. cit., p. 434. 
is "responsive, it is creative too"120, since it involves the possibility of the creation of a community and of the concomitant solidarity among its members.

In this regard, the situation of refugees fleeing from persecution has recently led Waldenfels to take up Lévinas' ethics of the Other and Derrida's reflections on hospitality in order to argue for a "responsive sort of politics" that bears in mind that refugees are fleeing from someone and something, be it a natural catastrophe, hunger, war, banishment, political or religious persecution. They are "guests on call (Gäste auf Abruf)"121, in a state of 'in-between': located neither where they come from nor where they flee to, they endure a 'waiting time' with no certain outcome. They are caught in an emotional state that oscillates between despair and hope, briefly put: refugees seek help. Waldenfels investigates the meaning of hospitality and argues for an unconditional hospitality that is nevertheless conditioned by circumstances, i.e. an "unconditional in the conditional (Unbedingtheit in der Bedingtheit), that varies according to conditions" 122 or circumstances. $\mathrm{He}$ understands by a "responsive sort of politics" a politics that "conceives means and ways to answer to challenges, requirements and claims." 123 Such a politics needs ethical impulses but cannot be reduced to or exhausted by them. It should rely on differentiated practices and modes of action, which neither denies nor seeks to evade difficulties by subterfuge. ${ }^{124}$

\section{The Mediatization of the Subject}

While Lévinas offers us relevant insights into the relationship between representation and humanization, Waldenfels provides us with the key to understand the creation of a community: solidarity based on reciprocal trust. In view of the humanitarian crisis we are facing, the development of an ethics based on the human subject's vulnerability that seeks to establish such a community proves to be urgently necessary. In this connection, there are good reasons to ground ethics on vulnerability: vulnerability is not only inherent in the human condition, i.e.

\footnotetext{
${ }^{120}$ Ibid., p. 435.

121 Waldenfels B., "Flüchtlinge als Gäste in Not", in Deutsche Zeitschrift für Philosophie, Band LXV, Heft 1, Berlin, de Gruyter, 2017, pp. 89-105, here p. 93.

122 Ibid., p. 98.

123 Idem.

${ }^{124}$ Idem. In the original: «Unter responsiver Politik verstehe ich eine Politik, die Mittel und Wege ersinnt, um auf Herausforderungen, Aufforderungen und Ansprüche zu antworten. Sie braucht ethische Impulse, erschöpft sich aber nicht darin [...]. Was aus diesem Dilemma herausführen könnte, wäre eine differenzierte Vorgehensweise, die Schwierigkeiten nicht leugnet, aber keine Ausflüchte sucht.»
} 
ontological, but it is also situational, that is, context specific. In the context of the mass exile phenomena today, vulnerability is exacerbated by the blunt exposure of refugees to the media. Violence can occur precisely because of their instrumentalization by the media: violence is inflicted upon subjects when their cultural idiosyncrasy is obliterated or, still worse, when their faces are used for extraneous ideological purposes. In view of this partisan manipulation of the image, it can be asked: in what ways can faces be humanized in Lévinas' sense?

Butler, taking up this theme, argues that vulnerability is a kind of relationship that belongs to a region where "receptivity and responsiveness" become the basis for mobilizing the public sphere. ${ }^{125}$ At present, this mobilization is mainly undertaken by modern media through the instrumentalization of representation. Even though it is commonly believed that those who are represented have a better chance of being heard, it seems that images do not always humanize. On the contrary, representation suspends the precariousness of life by de-realizing human suffering. It is Lévinas' emphasis on the impossibility of representing the face that renders this practice questionable. While the use of faces within the media is intended to expose their vulnerability, humanisation is paradoxically achieved when this presentation fails, i.e. which reveals the impossibility of a representation that accounts for the subject's humanity, as Butler rightly points out. ${ }^{126}$ This dehumanisation as brought about by the modern media is the main source of misunderstandings about fugitives or exiled persons. It is the medial formatting of the picture that produces the de-realisation of loss, an indifference towards human suffering and death, as J. Butler further stresses. ${ }^{127}$ The human subject thus becomes "mediatized", i.e. it does not simply become a product of the media, but is "reinterpreted by the sign form, articulated into models, and administered by the code", as Jean Baudrillard claims. ${ }^{128}$ In his words, the world becomes a simulacrum, such that both our perceptions and behaviour become steered by the media. Conversely, the 'actors' are required to adapt their behaviour to structures of the media. This is the case in crude media representations of refugees traversing the sea or 'imprisoned' in camps, a situation where military and police personnel exercise the power of surveillance and control, enforcing not only isolation, but also commanding how life is to be led. Refugees are especially vulnerable to media manipulation,

125 Butler J., "Rethinking Vulnerability and Resistance", in Butler J., Gambetti Zeynep, Sabsay Leticia (eds.), Vulnerability in Resistance, London, Duke Univ. Press, 2016, pp. 12-27, here p. 25.

126 Butler J., Precarious Life, op. cit., p. 144.

127 Ibid., p. 141.

128 Baudrillard J., For a Critique of the Political Economy of the Sign, Levin Ch. (transl.), St. Louis, MO: Telos Press, 1981, p. 175f. 
insofar as the media engage in gross violations of their privacy and their integrity. The media not only "frame" the subject, regulating the sphere of appearance, but also determine what counts as reality and what does not.

Hence, mediatization does not provide a neutral description of that which it represents. John B. Thompson understands by the term "mediatization", "the general process by which the transmission of symbolic forms becomes increasingly mediated by $[\ldots]$ the media industries." 129 When understood from a "social constructivist" point of view, as in the work of Andreas Hepp and Friedrich Krotz, the media have an active role in the process of the construction of socio-cultural reality. ${ }^{130}$ They define mediatized worlds as "structured fragments of social lifeworlds with [...] specific social practices"131, as such they are "the everyday concretization of media cultures and media societies." 132 Mediatization seems thus to be inextricably interwoven with our lifeworld in the phenomenological sense. But this interweaving is the result of a two-sided process, as Stig Hjarvard contends: on the one hand, the media emerge as independent institutions with their own logic to which other social institutions must accommodate themselves. On the other hand, the media are an integral part of other institutions insofar as their activities are performed through both interactive and mass media. ${ }^{133}$ Face-to-face communication has been thus replaced by mediated communication, wherein the relationship between the parties involved has been thoroughly altered. From a radical point of view, however, mediatization implies the collapse of "ontological divisions", the most radical collapse being that of the distinction between fact and fiction as Sheila Brown ${ }^{134}$, probably drawing on Baudrillard, rightly claimed long before our present age of "fake news" or "alternative facts". 135

To summarize, the mediatization of society is understood as the process whereby, as Stig Hjarvard puts it, "society is submitted to, or becomes dependent

129 Thompson John B., Ideology and Modern Culture, Cambridge, Polity Press, 1990, pp. 3-4.

130 Cf. Hepp Andreas, Krotz Friedrich, "Mediatized worlds: Understanding Everyday Mediatization", in Hepp A., Krotz F. (eds.), Mediatized worlds: Culture and Society in Media Age, London, Palgrave, 2014, pp. 1-15, here p. 3.

131 Ibid., p. 8.

132 Idem.

133 Hjarvard Stig, "The Mediatization of Society A Theory of the Media as Agents of Social and Cultural Change”, in Nordicom Review 29, (2008) 2, pp. 105-134.

134 Brown Sheila, Crime and Law in Media Culture. Buckingham: Open University Press, 2003, p. 22, as cited in Hjavard S., "The Mediatization of Society", art. cit., p. 111, original emphasis.

135 "Alternative facts" was a phrase used by U.S. Counselor to the President Kellyanne Conway during a Meet the Press interview on January 22, 2017, in which she defended White House Press Secretary Sean Spicer's false statement about the attendance numbers for Donald Trump's inauguration as President of the United States. Cf.: https://en.wikipedia.org/wiki/Alternative_facts. 
on, the media and their logic."136 Consequently, social interactions take place via the media. The media both link participants bridging physical distances but also detach the participants from their respective place-bound social contexts to which they bodily belong to. ${ }^{137}$ These insights reveal the importance of the face-to-face interaction: subjects establish a personal interaction that cannot efface the signs of vulnerability inscribed in the partner's face insofar as personal interactions require bridging the distance between the asymmetries of place and culture.

\section{Conclusion}

In conclusion, it seems that only a face-to-face encounter can enable the humanisation of the subject and allow the acknowledgment of the others' and our own vulnerability. This acknowledgement results from the exposure of both our bodily consciousness and flesh to worldly challenges and perils. But there is a certain ambivalence in the use of the media. In one way, all the faces displayed humanize the events that otherwise would not gain public recognition and thus force politics to respond. But do the images respect the humanity of these faces in each and every case? In order to be able to draw distinctions, we have to ask ourselves what narrative function media are fulfilling, and we must reveal the existential truth behind the veil of ideology. A work of criticism, of suspicion, is therefore urgently needed. Such criticism may induce the media to become the cultural means through which the human as such is respected and adequately represented, in Husserlian terms, by an image; an image that neither obliterates nor masks vulnerability and precariousness. But if we follow the Lévinasian view according to which faces in their suffering cannot be reduced to representation, then the image can stand as the veil which underlines this very impossibility. Mediatization would be avoided on both of these ways.

To provide such a criticism with a proper foundation and to return to the Other's and our humanity, we need to develop a vulnerability-centred ethics; an ethics that is based on both universal and particular demands that have their origin in universal ethical love and responsibility and that account for the particularities of the individual's situation. But these spiritual values must be complemented by a material axiology which, on the basis of our basic bodily needs, determines the basic human goods necessary to cover them. Theorists like Butler, Fineman,

136 Hjarvard S., “The Mediatization of Society”, art. cit., p. 113.

137 Ibid., p. 124. 
MacIntyre and Nussbaum have laid the basis for such an axiology: the existential, social and economic values disclosed therein account for the correlation between the modes of being of the body and the conditional qualities affecting it. This material axiology, in conjunction with spiritual values, would allow Husserl's and Levinas' ethics to become a praxis in which the responsive politics that Waldenfels demands can be carried out. The aforementioned considerations are intended only a first step towards this goal, which remains a task to be fulfilled.

Irene Breuer received her $\mathrm{PhD}$ in Philosophy at the University of Wuppertal in 2012. She holds both a degree in Architecture (1988) and in Philosophy (2003) from the Universidad de Buenos Aires, Argentina. Between 1991 and 2002 she worked in architecture and lectured at the Universities of Buenos Aires and Belgrano, Argentina. From 2012 to 2017 she lectured at the University of Wuppertal. In 2019 she was granted a DAAD scholarship to carry out research into the reception of the German Philosophical Anthropology in Argentina.

E-mail: ibreuer@hotmail.com 